\title{
Hematology of Swiss mice (Mus musculus) of both genders and different ages ${ }^{1}$
}

\author{
Tamy Ingrid Restel", Lenir Cardoso Porfirio" ${ }^{\mathrm{II}}$, Albert Schiaveto de Souza ${ }^{\mathrm{III}}$, Iandara Schettert Silva ${ }^{\mathrm{IV}}$
}

DOI: http://dx.doi.org/10.1590/S0102-86502014000500004

IFellow Master degree, Postgraduate Program in Health and Development, Federal University of Mato Grosso do Sul (UFMS), Campo Grande-MS, Brazil. Acquisition and interpretation of data, manuscript preparation.

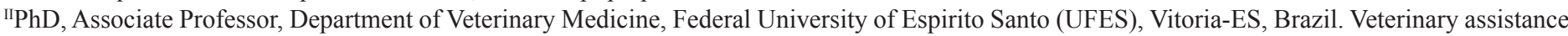
in the experimental study.

IIIPhD, Associate Professor, Center for Biological and Health Sciences, UFMS, Campo Grande-MS, Brazil. Statistical analysis.

${ }^{\text {IV }} \mathrm{PhD}$, Associate Professor, Department of Surgery, UFMS, Campo Grande-MS, Brazil. Conception and design of the study, manuscript writing.

\begin{abstract}
PURPOSE: To describe the hematologic values of male and female, young and adult, Swiss mice (Mus musculus).

METHODS: Mus musculus $(\mathrm{n}=14)$ were randomly selected and separated by gender. The male and female, young and adult animals were sedation to obtain a blood sample, by intracardiac route at 30, 45, 60, 75, 90, 105 and 120 days after birth.

RESULTS: The Swiss mouse hemogram values obtained, in relation to total eosinophils, basophils, and number of platelets, there was no statistical differences according to the genders or the age of the animals. Regarding the erythrocyte, hemoglobin and hematocrit values obtained, these were higher in females. The RDW-CD and MPV values were higher in the females than in the males.

CONCLUSIONS: Lymphocytes are the predominant cells in the peripheral blood. The collection of $800 \mu \mathrm{L}$ of blood by intracardiac route, every 15 days, did not affect the health of the animals. Analyses of the blood samples contribute to the experimental models provided by the Central Animal Facility of UFMS and used by professors.
\end{abstract}

Key words: Erythrocytes. Leukocytes. Blood Platelets. Mice. 


\section{Introduction}

Technological refinements in the generation of experimental models have led to a reduction in the number of animals per experimental group, principally due to reducing the variability observed in each experiment. Thus, the reflection regarding the need for a biological model and the relevance of the study should be key aspects in the researcher's decision to undertake a project using animals ${ }^{1}$, however, the trusted rules for the validation of the extrapolation from one species to another should be evaluated in each experiment and can be verified after the first studies with the live species ${ }^{2}$. For this, reference values must be established, with it being necessity to know the individual biochemical parameters of animals used. These references serve as the parameters for evaluating changes in different organs ${ }^{3}$.

For reference data in the literature, the variation in the values must be considered in relation to species, methods of sample collection, handling and analysis ${ }^{4}$, since the cure of many human diseases due to animal testing 5 .

In the present work, the animal species chosen was the Swiss mice (Mus musculus), with males and females at different ages, and blood samples obtained by the intracardiac route for verification of the hematological parameters.

\section{Methods}

All the procedures performed in this work were submitted to and approved by the UFMS Ethics Committee under protocol $\mathrm{n}^{\circ}$ 354 of $20 / 10 / 2012$.

To achieve the aims of this study, 14 Swiss mice (Mus musculus) were randomly selected and separated by gender. Females and males were separated and divided into four polypropylene cages measuring 30x20x13 cm each, with 4 and 3 animals. The animals were kept in ventilated shelving with temperature, humidity and photoperiod of 12/12 hour controlled for the species. Vented shelves were placed in the experimentation room with a temperature of $18^{\circ} \mathrm{C}$ to keep them at a temperature of $23^{\circ} \mathrm{C}$ and $60 \%$ humidity. Each box was provided with CR1Nuvital Nuvilab ${ }^{\circledR}$ commercial feed and water ad libitum, without fasting time for obtaining the blood samples. All the animals were weighed before the beginning of each procedure.

The animals, which came from the Animal Facility

and were kept in the experimentation sector, were sedated with 0.05 $\mathrm{ml} \mathrm{Xylazine}{ }^{\circledR}$ as a muscle relaxant and $0.1 \mathrm{ml}$ of Ketamine ${ }^{\circledR}$ for deep analgesia, at a dilution of $0.15 \mathrm{ml}$ per animal, by the intramuscular route $^{6}$, for containment and by the intracardiac route at 30, 45, 60, 75,
90, 105 and 120 days after birth to obtain the blood samples., Using a disposable $1 \mathrm{ml}$ syringe and a $26 \mathrm{x} 6 \mathrm{~mm}$ needle, $0.8 \mathrm{ml}$ of whole blood was obtained from each animal and stored in $0.4 \mathrm{ml}$ pediatric vials with $10 \mu \mathrm{L}$ anticoagulant for the measurement of the hematological parameters: erythrocytes $(\mathrm{Hm})$, hemoglobin $(\mathrm{Hb})$, hematocrit $(\mathrm{Ht})$, mean corpuscular volume (MCV), mean corpuscular hemoglobima $(\mathrm{MCH})$ and mean corpuscular hemoglobin concentration (MCHC), total platelets (PLT), total leukocytes (TL), red cell distribution width related to standard deviation (RDW-SD), red cell distribution width related to corpuscular volume (RDW-CV), and mean platelet volume (MPV). The parameters were measured using a Sysmex XE2100 device, from the Clinical Laboratory of the University Hospital.

The leukocyte count was performed under immersion, with a Olympus ${ }^{\circledR}$ CX 41 light microscope, and 26x76mm microscopic slides, and the blood distension stained using the Laborclin ${ }^{\circledR}$ brand Panoptic rapid method. The slides were microphotographed using a Leika DM, 5.500 B device, from the Laboratory of Image Capture of CCBS/UFMS. The results were evaluated using the two-way repeated measures ANOVA test, and the interactions and ages for each gender were compared using the one-way repeated measures ANOVA test, followed by Tukey's post-test, whereas the genders, at each age, were compared using the Student's t-test. The statistical analysis was performed using the Sigmastat ${ }^{7}$, version 2.0 software, considering a significance level of $5 \%$.

After the completion of the blood collection from the groups, the animals were euthanized with Sodium Thiopental, at a lethal dose of $100 \mathrm{mg} / \mathrm{kg}$, by the intraperitoneal route.

\section{Results}

The results are shown in the text, in which the means and standard deviations of the leukocyte parameters are described.

In the two-way repeated measures ANOVA test, regarding the amount of total leukocytes, there was no significant effect for gender $(\mathrm{p}=0.123)$, however, there was a significant effect for animal age $(\mathrm{p}<0.001)$ and there was an interaction between gender and age $(\mathrm{p}=0.002)$. The total amount leukocytes in the males at 90 days was greater than that for the males at 45, 75 and 105 days (Tukey's posttest, $\mathrm{p}<0.05$ ). The amount of total leukocytes in the males at 60 days was greater than that in the males at 75 and 105 days $(p<0.05)$. For the females, there was no difference in the total amount leukocytes according to age $(p>0.05)$. Also regarding total leukocytes, there was no difference between the genders, however, in the animals at $30,45,75$ and 105 days the number of total leukocytes was higher in the females $(\mathrm{p}<0.05)$, and in the animals at 60,90 and 120 days the number was higher in the males $(\mathrm{p}<0.05)$. 
Concerning the percentage of neutrophils, there was a significant effect according to gender $(p=0.003)$ and age $(p<0.001)$, however, there was no interaction between gender and age $(\mathrm{p}=0.204)$. The percentage of neutrophils in the animals at 30 days was greater than the percentage at 60,90, 105 and 120 days and at 45 days it was higher than at 90 and 120 days. Also regarding the percentage of neutrophils in the comparison between genders, the values were higher for the males than for the females $(\mathrm{p}<0.05)$.

Regarding the percentages of lymphocytes, there was a significant effect according to gender $(\mathrm{p}=0.001)$, an effect according to the age of the animal $(\mathrm{p}<0.001)$, and no interaction between gender and age $(p=0.223)$. Furthermore, the number of lymphocytes in the animals of 90, 60, 105 and 120 days were higher than in the animals at 30 and 45 days, with the number of lymphocytes being higher in the females compared to the males $(p<0.05)$.

Regarding the percentage of monocytes, the two-way ANOVA test showed a significant effect according to gender $(p=0.008)$ and age $(p<0.001)$, however, there was no interaction between gender and age $(p=0.275)$. In Tukey's post-test, $(p<0.05)$ the number of total leukocytes were greater at 30 days than at 45 , $60,75,90,105$ and 120 days, and the percentages of monocytes were higher in the males than in the females $(p<0.05)$.

The relative values of eosinophils showed no significant effect according to gender $(p=0.277)$ and age $(p=0.057)$, and there was no interaction between gender and age $(p=0.156)$. These results were also observed for the percentages of basophils, with no difference between the genders $(\mathrm{p}=0.603)$, no effect according to age $(\mathrm{p}=0.866)$, and no interaction between gender and age $(p=0.675)$. The leukocytes are shown in Figures 1 and 2.



FIGURE 1 - Immersion photomicrographs (x100) of blood smears of Swiss lineage male mice. Immersion objective, stained with Panoptic. Neutrophil (A), lymphocyte (B) monocyte (C), eosinophil (D), polychromatic erythrocyte (E), and platelets (F).

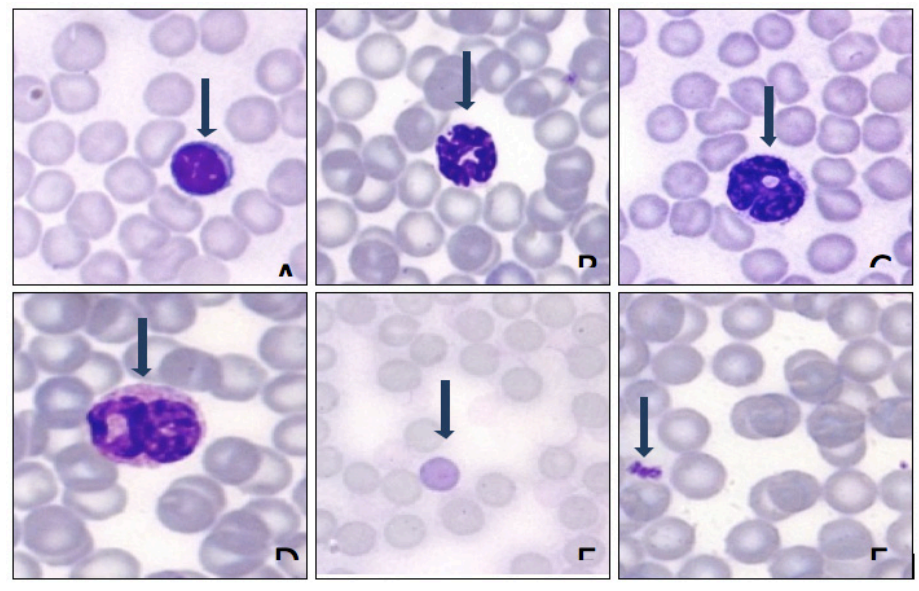

FIGURE 2 - Immersion photomicrographs (x100) of blood smears of Swiss lineage female mice. Immersion objective, stained with Panoptic. Neutrophil (A), lymphocyte (B), monocyte (C), eosinophil (D), polychromatic erythrocyte (E), and platelets (F).

Regarding the erythrocyte mean values, there were effects according to both gender $(p=0.025)$ and the age of the animals $(p<0.001)$, however, there was no interaction between these variables $(p=0.137)$. Generally, the females presented greater quantities of erythrocytes than the males $(p<0.05)$. Comparing the ages, in both genders, at 90 days, the mean values of erythrocytes were higher than at 30 and 45 days. Furthermore, at 75 and 105 days, the values were higher than at 30 days $(\mathrm{p}<0.05)$.

In relation to the mean hemoglobin values, there was an effect for gender $(\mathrm{p}=0.012)$ as well as for the age of the animals $(p=0.070)$, however, there was no interaction between these variables $(p=0.127)$. There was no significant difference in the amount of hemoglobin when comparing the ages. Overall, the females presented greater quantities of hemoglobin than the males $(p<0.05)$.

In relation to the hematocrit values obtained there was an effect for both gender $(\mathrm{p}=0.015)$ and age $(\mathrm{p}=0.040)$, however, there was no interaction between gender and age $(p=0.435)$. Overall, the females presented greater quantities of erythrocytes than the males $(p<0.05)$. In the post-test there was no significant difference between the different ages regarding the hematocrit values obtained.

Concerning the MCV values obtained, there was no effect according to gender $(\mathrm{p}=0.587)$ and no interaction between gender and age $(p=0.400)$, however, there was an effect for the age of the animals $(\mathrm{p}<0.001)$. Overall, there was no significant difference between the genders $(p<0.05)$. When comparing the ages, in both genders at 30 days, the mean MCV values were higher than at 45, $60,75,90,105$ and 120 days. Furthermore, at 120 days the values were higher than at 60 days $(\mathrm{p}<0.05)$.

In relation to the $\mathrm{MCH}$ values obtained, there was no effect according to gender $(\mathrm{p}=0.587)$ and no interaction between gender and age $(p=0.400)$, however, there was an effect for the age 
of the animals $(\mathrm{p}<0.001)$. For the males, the $\mathrm{MCH}$ values at 30 days were higher than at 45, 60, 75, 90, 105 and 120 days (Tukey's post-test, $\mathrm{p}<0.05)$. In addition, the $\mathrm{MCH}$ values for the animals at 45 days were greater than at 105 days $(\mathrm{p}<0.05)$. Also in relation to the $\mathrm{MCH}$, there was no difference between the genders,

For the MCHC values obtained, there was no significant difference according to gender $(\mathrm{p}=0.897)$ and no interaction between gender and age $(\mathrm{p}=0.282)$, however, there was an effect for age $(p<0.001)$. Regarding the effect between the genders, no significant difference was presented, however, the animals at 60 days presented higher values than at 30 and 120 days, and at 45, 90 and 105 days the values were greater than at 30 days.

Regarding the mean platelets values there was no significant affect for either gender $(p=0.745)$, or age $(p=0.136)$, and there was also no interaction between gender and age $(\mathrm{p}=0.293)$.

For the mean RDW-SD values no effect was observed for gender $(p=0.422)$ and there was no interaction between gender and age $(p=0.364)$, however, there was an effect for age $(p<0.001)$ on the values of this variable. Similarly there was no effect when comparing the genders, however, in relation to age, the animals presented higher values at 30 days than at 45, 60, 75, 90, 105 and 120 days $(\mathrm{p}<0.05)$.

For the mean values of the RDW-CV variable there was no effect for either the gender $(p=0.006)$ or the age of the animals $(p<0.001)$, with no interaction between these variables $(p=0.415)$. Overall, the females presented greater RDW-CV values than the males $(p<0.05)$. When comparing the ages, in both genders, the mean values were higher at 30 and 75 days than at 45 and 60 days. Furthermore, at 60, 90, 105 and 120 days, the values were higher for the animals than at 45 days $(\mathrm{p}<0.05)$.

Regarding the MPV values obtained, there was an effect for both gender $(p=0.025)$ and the age of the animals $(p<0.001)$, with no interaction between these variables $(p=0.137)$. Overall, the females presented greater MPV values than the males $(p<0.05)$. When comparing the ages, in both genders, the mean MCV values were higher at 30 days than at 45, 90, 105 and 120 days. Furthermore, at 60 and 75 days the values were higher for the animals than at 105 days $(\mathrm{p}<0.05)$.

\section{Discussion}

For the Swiss strain, Branco et $a .^{8}$ reports leukocyte values in the blood of male mice $\left(6.9 \pm 0,6 \times 10^{3} / \mathrm{mm}^{3}\right)$ and values for females $\left(5.8 \pm 0.5 \times 10^{3} / \mathrm{mm}^{3}\right)$ at different ages. Ponte ${ }^{9}$ presented $8.725 \pm 0.6 / \mathrm{mm}^{3}$ and $7.640 \pm 0.5 / \mathrm{mm}^{3}$, for males and females, respectively. In research with animals Verçosa Júnior et al. ${ }^{10}$ presented mean values, in females of 25 to $30 \mathrm{~g},\left(2.96 \pm 1.22 \times 10^{3} /\right.$ $\mathrm{mm}^{3}$ ); and Moreira ${ }^{12}$ found values for males of $2.81 \pm 0.39 \times 10^{3 /}$ $\mathrm{mm}^{3}$, lower than the total leukocytes values obtained in the present work. When comparing the absolute values of $5.04 \pm 1.84 / \mu \mathrm{L}$ to $3.07 \pm 1.20 / \mu \mathrm{L}$ for females and $4.92 \pm 2.29 / \mu \mathrm{L}$ to $3.97 \pm 2.64 / \mu \mathrm{L}$ for males, with higher values in younger animals in this study, it can be observed that, regardless of age, they are similar to the values of Melo et al. ${ }^{14}(5.166 / \mu \mathrm{L})$; Priatel et al. ${ }^{15}(5.100 \pm 2.200 / \mu \mathrm{L})$; Reis, et al. ${ }^{14}(5.825 .5 \pm 246.4 / \mu \mathrm{L})$, but differed from the lower values of Verçosa Júnior et al. ${ }^{10}\left(1.99 \pm 0.89 \times 10^{3} / \mathrm{mm}^{3}\right)$.

The present study is in agreement with that of Doeing et al. ${ }^{11}$ which, in many animal models investigating various diseases, there is a need to find the number of total and differential leukocytes, as it is necessary that each Animal Facility have their normal values for sanitary control of the animals. In this study, even using healthy animals, in general significant differences were observed among the ages and genders of the animals.

For Branco et $a l^{8}$ the neutrophil values for males from $21.8 \pm 1.6 \%$ and for females $19.6 \pm 1.9 \%$ at different ages; Ponte ${ }^{9}$ obtained values for males and females of $27.8 \pm 5.2 \%$ and $32.8 \pm 4.6 \%$ respectively, whereas in the present study values of $18.30 \pm 6.04 \%$ for females days were found at 30 , reducing proportionally to $7.63 \pm 2.80 \%$ at 120 days, and of $19.74 \pm 4.71 \%$ for males at 30 days reducing to $14.97 \pm 3.52 \%$ at 120 days, with values similar to those observed by Vasconcelos et al. ${ }^{13}$ with $18.40 \pm 1.94 \%$ for adult animals. Regarding the absolute values of the present study, the absolute neutrophil values were $922.32 / \mu \mathrm{L}$ at 30 days of age to $234.24 / \mu \mathrm{L}$ at 120 days in the females and $971.21 / \mu \mathrm{L}$ at 30 days to $549.31 / \mu \mathrm{L}$ at 120 days in the males. For neutrophils at 60 days a value of $483.3 / \mu \mathrm{L}$ was obtained for the females and $784.85 / \mu \mathrm{L}$ for the males, which are similar to Melo et $a l .{ }^{14},(516.0 / \mu \mathrm{L})$ and Verçosa Júnior et al. ${ }^{10}\left(0.25 \pm 0.21 \times 10^{3} / \mathrm{mm}^{3}\right)$ for females, however differed from Reis, et al. ${ }^{14}$ who presented $1575.7 \pm 313 / \mu \mathrm{L})$ and from Priatel et al. ${ }^{15}(1000 \pm 290 / \mu \mathrm{L})$. In this study, it can be observed that, as the age increased the neutrophils decreased and lymphocytes increased inversely.

For lymphocytes, Branco et al. ${ }^{8}$ obtained values of $73.1 \pm 1.6 \%$ for males, and $74.5 \pm 2.1 \%$ for females. Ponte ${ }^{9}$ presented mean values of $68.5 \pm 63.6 \%$ for males and $63.6 \pm 4.7 \%$ for females and Vasconcelos et al. ${ }^{13}$ presented values of $77.60 \pm 3.70 \%$, with these values being lower than those obtained in this experiment, in which the minimum and maximum values for males were $78.09 \pm 4.37 \%$ and $87.74 \pm 3.58 \%$, and for females $79.86 \pm 4.61 \%$ and $91.54 \pm 2.91 \%$.

Branco et al. ${ }^{8}$ presented monocyte values of $3.7 \pm 0.3 \%$ and $5.3 \pm 0.6 \%$ for males and females at different ages; Ponte ${ }^{9}$ 
obtained values of $3.3 \pm 0.5 \%$ for males and $3.6 \pm 0.4 \%$ for females; Vasconcelos et al..$^{13}$ presented the value of $2.00 \pm 0.35 \%$ without specifying gender, which is between the relative values of this study, with $3.09 \pm 1.74 \%$ for females at 30 days and $0.64 \pm 0.71 \%$ at 120 days, while for males this value was $2.93 \pm 1.29 \%$ at 30 days and $1.43 \pm 0.88 \%$ at 120 days. Regarding the absolute values, Melo et al. ${ }^{14,}$ obtained $0.124 / \mu \mathrm{L}$ for females; in the present study a value of $155.74 / \mu \mathrm{L}$ was obtained for females at 30 days and $19.65 / \mu \mathrm{L}$ at 120 days, and $144.16 / \mu \mathrm{L}$ for males at 30 days and $56.77 / \mu \mathrm{L}$ at 120 days, being lower than the values obtained by Priatel et al. ${ }^{15}$ $(340.0 \pm 150.0 / \mu \mathrm{L})$ and Verçosa Júnior et al. ${ }^{16}\left(250.0 \pm 120.0 / \mathrm{mm}^{3}\right)$. It can be observed that the values of the present study decreased as the animals became older.

The values for the number of eosinophils presented by Branco et al. ${ }^{8}$ were $0.8 \pm 0.2 \%$ for males, and $0.6 \pm 0.2 \%$ for females; by Ponte $9,2.4 \pm 0.55 \%$ for males and $2.0 \pm 0.55 \%$ for females; and by Vasconcelos et al. ${ }^{13}, 0.36 \pm 0.05 \%$ for males, while in this study, the maximum values were $0.19 \pm 0.23 \%$ for males and $0.09 \pm 0.23 \%$ for females, with minimum values of $0 \%$. This comparison shows lower values that those of the authors cited, without a significant difference between males and females for eosinophil numbers. Regarding the absolute values, Reis et $a l .{ }^{12}$ obtained values of $61.5 \pm 41.6 / \mu \mathrm{L}$, without specifying age or gender, higher than in the present work, with absolute maximum values of $3.04 / \mu \mathrm{L}$ for females at 105 days, and $12.20 / \mu \mathrm{L}$ for males of 90 days.

Branco et al. ${ }^{8}$ observed values of $0 \%$ in basophiles for males and females of different ages. Other authors did not present values different from zero for this parameter, while the animals studied here obtained percentage of basophiles in the blood of $0.13 \pm 0.23 \%$ for the males and a maximum of $0.10 \pm 0.26 \%$ and minimum of $0.03 \pm 0.08 \%$ for the females, despite not having presented any significant difference in relation to gender or age. Regarding the absolute values, the females presented maximum values of $4.54 / \mu \mathrm{L}$ at 45 days and minimum values of $1.17 / \mu \mathrm{L}$ at 90 days, while the males presented peak values of $8.35 / \mu \mathrm{L}$ at 90 days and a minimum value of $0.00 / \mu \mathrm{L}$ at 45 days.

Regarding the erythrogram, from the studies of Branco et $a l .{ }^{8}$ it can be verified that values were obtained for erythrocytes of $9.4 \pm 0,1 \times 10^{6} / \mathrm{mm}^{3}$ for males, while for females these were $9.2 \pm 0.2 \times 10^{6} / \mathrm{mm}^{3}$; Reis et al. ${ }^{12}$ presented the value of $5.1 \pm 0.3 \times 10^{6} / \mathrm{mm}^{3}$, which was not associated with gender; Ponte ${ }^{9}$ presented the values of $5.7 \pm 0.1 \times 10^{6} / \mathrm{mm}^{3}$ and $5.1 \pm 0.1 \times 10^{6} /$ $\mathrm{mm}^{3}$ for males and females respectively; Verçosa Júnior et al. ${ }^{10}$ presented $7.23 \pm 1.74 \times 10^{6} / \mathrm{mm}^{3}$ for females; Vasconcelos et al. ${ }^{13}$ $8.66 \pm 0.36 \times 10^{6} / \mathrm{mm}^{3}$ for males; Melo et al. ${ }^{14}, 9,658,000 / \mu \mathrm{L}$ for females; and Priatel et al. ${ }^{15}, 8,730 \pm 410 \times 10^{3} / \mathrm{mm}^{3}$. The present study obtained erythrocyte values similar to the other authors cited for male mice, with $9.51 \pm 0.63 \times 10^{6} / \mu \mathrm{L}$ as the maximum value and $7.94 \pm 0.42 \times 10^{6} / \mu \mathrm{L}$ as the minimum value. The number of red blood cells was lower in the males than in the females, with observed maximum values of $9.80 \pm 0.46 \times 10^{6} / \mu \mathrm{L}$ in the animals at 120 days and minimum values of $8.24 \pm 0.97 \times 10^{6} / \mu \mathrm{L}$ at 30 days.

Branco et $a l .{ }^{8}$ showed hemoglobin values for males of $13.6 \pm 0.2 \mathrm{~g} / \mathrm{dL}$ and for females of $13.5 \pm 0.3 \mathrm{~g} / \mathrm{dL}$; Reis et al. ${ }^{12}$ presented $12.1 \pm 0.6 \mathrm{~g} / \mathrm{dL}$ without specifying gender; Ponte ${ }^{9}$, $17.4 \pm 0.9 \mathrm{~g} / \mathrm{dL}$ and $15.0 \pm 0.9 \mathrm{~g} / \mathrm{dL}$ for males and females respectively; Melo et al. ${ }^{14}, 17.78 \mathrm{~g} / \mathrm{dL}$ for females; Priatel et al. ${ }^{15}$, $14.8 \pm 2.0 \mathrm{~g} / \mathrm{dL}$; Vasconcelos et al. ${ }^{13}, 13.36 \pm 1.10 \mathrm{~g} / \mathrm{dL}$ for males, similar to the values obtained in this study, with $14.68 \pm 0.75 \mathrm{~g} / \mathrm{dL}$ as the maximum values at 90 days and $12.90 \pm 4.29 \mathrm{~g} / \mathrm{dL}$ as minimum value for males at 120 days of life. For the females the maximum values were $15.30 \pm 0.77 \mathrm{~g} / \mathrm{dL}$ at 120 days and $13.59 \pm 1.28 \mathrm{~g} /$ $\mathrm{dL}$ as the minimum values. These values are greater than those of Verçosa Júnior et al. ${ }^{10}$, who presented values of $10.7 \pm 2.55 \mathrm{~g} /$ $\mathrm{dL}$ for females. The values that were obtained, differ from those of Ponte ${ }^{9}$ and Melo et al. ${ }^{14}$, however, there was a difference in the comparison between age and gender. In the present study the females presented higher values than the males in relation to the hemoglobin parameter.

The authors who serve as references for this work have presented the following hematocrit values: Branco et $a l .{ }^{8}, 41,2 \pm 0,6 \%$ for males and $40.0 \pm 1.0 \%$ for females; Reis et al. ${ }^{12}, 42.7 \pm 1.7 \%$ not related to gender; Verçosa Júnior et al. ${ }^{10}$, $30.86 \pm 7.78 \%$ for females; Vasconcelos et al. ${ }^{13} 40.76 \pm 1.35 \%$ for males, In the present study the minimum and maximum values for hematocrit were $45.10 \pm 5.0 \%$ and $48.84 \pm 3.4 \%$ for males, and $45.10 \pm 5.04 \%$ and $52.06 \pm 2.32 \%$ for females, being higher than the values reported by these authors. However, these are similar to the values of $47.7 \%$ reported by Melo et al. ${ }^{14}$ for females; $45.8 \pm 1.5 \%$ by Priatel et al. ${ }^{15}$; and $52.8 \pm 1.3 \%$ for males and $44.4 \pm 1.1 \%$ for females by Ponte 9 . There was no significant difference in hematocrit values according to age. In the comparison between the genders, females presented higher values than males.

Regarding the mean corpuscular volume (MCV) values, Branco et al. ${ }^{8}$ reported $43.6 \pm 0.6 \mathrm{fL}$ for males and $43.3 \pm 0.4 \mathrm{fL}$ for females; Reis et al. ${ }^{12}$ presented $83.8 \pm 3.7 \mathrm{fL}$ not related to gender; and Ponte $^{9}$ 93.4 \pm 1.2 and $87.7 \pm 1.1 \mathrm{fL}$ for males and females respectively. In the comparison it can be observed that these values are greater than those of the present study, in which the lowest value was $51.69 \pm 1.17 / \mathrm{fL}$ for females at 60 days, and the highest was $59.50 \pm 6.49 / \mathrm{fL}$ for females at 30 days of life. For the males of the same ages these values were $50.61 \pm 2.28 / \mathrm{fL}$ and $59.56 \pm 4.31 / \mathrm{fL}$ 
respectively, with no significant difference between the genders. These are similar to the values obtained by Rodrigues ${ }^{17}$ (52.5 \pm 1.6 $\mu^{3}$ ) and quantitatively greater than those of Verçosa Júnior et al. ${ }^{10}$ for females (42.57 $\pm 1.13 \mathrm{fL})$; Vasconcelos et al. ${ }^{13}\left(48.60 \pm 1.32 \mu^{3}\right)$ for males; and Melo et al. ${ }^{14}$ (49.2 fL) for females.

Regarding the mean corpuscular hemoglobin (MCH), a difference was found between the values obtained in the present study and the values that Branco et al. ${ }^{8}$ presented for males $14.5 \pm 0,2$ $\mathrm{pg}$ and females $14.6 \pm 0,1 \mathrm{pg}$ and that presented by Reis et al. ${ }^{12}$ $(23.6 \pm 1.2 \mathrm{pg})$ who did not specify gender, with the minimum of the present study being $15.46 \pm 0.08 / \mathrm{pg}$ at 75 days and the maximum $16.54 \pm 0.71 / \mathrm{pg}$ at 30 days for males, and $15.46 \pm 0.08 / \mathrm{pg}$ and $16.71 \pm 1.23 / \mathrm{pg}$ for females of the same ages, with no significant difference between the genders. These values are similar to those of Verçosa Júnior et al. ${ }^{10}$ with $15 \pm 1 \mathrm{pg}$ for females; Vasconcelos et al. ${ }^{13}$ with $15.56 \pm 0.51 \mu \mathrm{g}$ for males; and lower than the values of Melo et al. ${ }^{14}$ with $16.32 \mathrm{pg}$ for females, and Priatel et al. ${ }^{15}$, with $16.9 \pm 0.8 \mathrm{pg}$.

The comparative values obtained by other researchers for MCHC are: Branco et al. ${ }^{8}, 33.1 \pm 0.3 \mathrm{~g} / \mathrm{dL}$ and $33.6 \pm 0.2 \mathrm{~g} / \mathrm{dL}$ for males and females at different ages; Ponte ${ }^{9}, 32.8 \pm 0.3 \%$ and $33.1 \pm 0.3 \%$ for males and females respectively; Verçosa Júnior et al. ${ }^{10}, 34.57 \pm 2.57 \%$ for females; Vasconcelos et al. ${ }^{13}, 32.54 \pm 0.55 \%$ for males; Melo et $a l .{ }^{14}, 33.02 \mathrm{~g} / \mathrm{dL}$ for females; and Priatel et al. ${ }^{15}, 32.3 \pm 1.0 \%$ with values greater than the MCHC after the tests and which ranged from $28.00 \pm 2.27 \mathrm{~g} / \mathrm{dL}$ to $30.74 \pm 0.91 \mathrm{~g} / \mathrm{dL}$ in the females of 30 and 45 days, and $28.23 \pm 2.98 \mathrm{~g} / \mathrm{dL}$ to $30.74 \pm 0.91 \mathrm{~g} / \mathrm{dL}$ for the males of 30 and 60 days. These values were similar to the study of Reis et al. ${ }^{12}$, $(28.3 \pm 0.8 \%)$, in which gender is not mentioned. In the comparison between genders, there was no significant difference between males and females in the present study.

It is important to note that Monteiro ${ }^{17}$ reported that together the RDW and MCV parameters, particularly macrocytic $\mathrm{MCV}$, may help in the differential diagnosis of various diseases, especially some types of anemia. Considering that the animals were healthy, these values are within normal limits. In comparing the ages, the RDW-SD values were higher in the animals at 30 days, with no significant difference found when comparing the genders. There was no information from other authors for the Swiss strain.

Regarding the presence of polychromasia, in the present study this could be seen on the slides, with Verçosa Júnior et al. ${ }^{16}$ encountering $4.3 \pm 0.78 / \mu \mathrm{L}$ reticulocytes in the control animals. In the present study polychromasia occurred in the blood smears. This fact has been well observed in animals of 30 to 45 days, in which the amount of young cells per field are present in greater numbers than is the case for older animals, in which they are less evident.
Monteiro ${ }^{17}$ writes that, in humans, correlation studies show that the RDW-CV is high compared to the microcytic MCV. When comparing the genders, this study showed that females presented higher values than males, however, without presenting anemia, as in the study of Priatel et al. ${ }^{15}$ which showed RDW-CV values of $16.7 \pm 1.1 \%$ in mice, similar to the values of the present study.

Comparing the values obtained for platelets, Branco et al. ${ }^{8}$ presented the value of $810.0 \pm 55.1 \times 10^{3} / \mathrm{mm}^{3}$ for males and females with $1030.0 \pm 55.0 \times 10^{3} / \mathrm{mm}^{3}$, while the present study found lower values for females with the minimum of $427.86 \pm 231.5010^{3} / \mu \mathrm{L}$ and the maximum of $765.71 \pm 181.8210^{3} / \mu \mathrm{L}$ at the ages 45 and 75 days. Values of $659.63 \pm 168.76$ and $458.63 \pm 241.63$ were obtained for the males of 90 and 120 days respectively. These values are similar to those obtained by Reis et al. ${ }^{12},(618.3 \pm 35.7 / \mu \mathrm{L})$ who did not specify gender, Melo et al. ${ }^{14}$, $(487.600 / \mu \mathrm{L})$ for females, and Priatel et al. ${ }^{15}$, $\left(882 \pm 133 \times 10^{3} / \mathrm{mm}^{3}\right)$. The values are greater than those of Ponte ${ }^{9}$ (243.8 $\pm 34.1 / \mathrm{mm}^{3}$ for males and $301.6 \pm 30.5 / \mathrm{mm}^{3}$ for females), and Vasconcelos et al. ${ }^{13}\left(254.00 \pm 17.20 \times 10^{3} / \mathrm{mm}^{3}\right)$ for males.

Regarding the amounts of MPV, for Faria and Dal Bó ${ }^{18}$ the evaluation of platelet size and morphology is useful in the diagnosis of patients with platelet disorders, therefore the MPV is of great importance, particularly regarding thrombocytopenia and thrombocytosis in mice. Priatel et al. ${ }^{17}$ obtained values of $4.3 \pm 0.2$ $\mathrm{fL}$, much lower than in this study, in which the maximum value for females was $8.07 \pm 0.78 \mathrm{fL}$ at 30 days and the minimum 7.10 \pm 0.70 $\mathrm{fL}$ at 90 days, for the males these values were $7.71 \pm 0.53 \mathrm{fL}$ at 30 days and $7.03 \pm 0.19 \mathrm{fL}$ at 105 days.

\section{Conclusions}

As Mus musculus age, the numbers of neutrophils decrease in relation to the lymphocytes, which are the predominant cells in the peripheral blood.

The collection of $800 \mu \mathrm{L}$ of blood by intracardiac route, every 15 days, did not affect the health of the animals.

It was possible to obtain values, with samples obtained by cardiac puncture at different ages and from different genders of Swiss mice.

The values obtained in this study will serve as references for researchers of UFMS working with Swiss mice.

\section{References}

1. Damy SB, Camargo RS, Chammas R, Figueiredo LFP. Aspectos fundamentais da experimentação animal: aplicações em cirurgia experimental. Rev Assoc Med Bras. 2010;56(1):103-11.

2. Fagundes DJ, Taha MO. Modelo animal de doença: critérios 
de escolha e espécies de animais de uso corrente. Acta Cir Bras. 2004;19(1):65-9.

3. Almeida AS, Faleiros ACG, Teixeira DNS, Cota UA, Chica JEL. Valores de referência de parâmetros bioquímicos no sangue de duas linhagens de camundongos. J Bras Patol Med Lab. 2008;44(6):429-32.

4. Schneck K, Washington M, Holder D, Lodge K, Motzel S. Hematologic and serum biochemical reference values in nontransgenic FVB mice. Comp Med. 2000;50(1):32-5.

5. Chorilli M, Michelin DC, Salgado HRN. Animais de laboratório: o camundongo. Rev Ciênc Farm Básica Apl. 2007;28(1):11-23.

6. Schanaider A, Silva PC. Uso de animais em cirurgia experimental. Acta Cir Bras. 2004;19(4):441-7.

7. Sigmastat. Sigmastat Statistical Software: version 2.0. SPSS Science; 1999

8. Branco ACSC, Diniz MFFM, Almeida RN, Santos HB, Oliveira KM, Ramalho JA, Dantas JG. Parâmetros bioquímicos e hematológicos de Ratos Wistar e Camundongos Swiss do Biotério Professor Thomas George. Rev Bras Cienc Saúde. 2011;15(2):209-14.

9. Ponte FLR, Silva AAR, Maia MBS. Bee-honey, propolis and Eucalyptus globulus extract: pre-clinical toxicity study in Rodents. Pharmacogn Mag. 2008;4:66-74.

10. Verçosa Júnior D, Melo MM, Dantas-Barros AM, Gomes AM, Silva Júnior PG, Lago EP. Quadro hematológico e peso do baço de camundongos com tumor de Ehrlich na forma sólida tratados com Agaricus blazei. Rev Bras Farmacogn. 2004;14(supl. 1):32-4.

11. Doeing DC, Borowicz JL, Crockett ET. Gender dimorphism in differential peripheral blood leukocyte counts in mice using cardiac, tail, foot, and saphenous vein puncture methods. BMC Clin Pathol. 2003;3(3):1-6.

12. Reis CMF, Carvalho JCT, Caputo LRG, Patrício KCM, Barbosa MVJ, Chieff AL, Bastos JK. Atividade anti-inflamatória, antiúlcera gástrica e toxicidade subcrônica do extrato etanólico de própolis. Rev Bras Farmacogn. 2000;9(10):43-52.

13. Vasconcelos TH, Modesto-Filho J, Diniz MFFM, Santos HB, Aguiar FB, Moreira PVL. Estudo toxicológico pré-clínico agudo c om o extrato hidroalcoólico das folhas de Cissus sicyoides L. (Vitaceae). Rev Bras Farmacogn. 2007;17(4):583-9.

14. Melo MM, Verçosa Jr D, Pinto MCL, Silveira JB, Ferraz V, Ecco R, Paes PRO. Intoxicação experimental com extratos de Mascagnia rigida (Malpighiaceae) em camundongos. Arq Bras Med Vet Zootec. 2008;60(3):631-40.
15. Priatel JJ, Sarkar M, Schachter H, Marth JD. Isolation, characterization and inactivation of the mouse Mgat3 gene: the bisecting $\mathrm{N}$-acetylglucosamine in asparagine-linked oligosaccharides appears dispensable for viability and reproduction Glycobiology. 1997;7(1):45-56.

16. Verçosa Júnior D, Souza-Fagundes EM, Cassali GD, Ribeiro EL, Zani CL, Melo MM. Efeito do miriadenolídeo isolado de Alomia myriadenia (Asteraceae) sobre o tumor de Ehrlich ascítico no camundongo. Arq Bras Med Vet Zootec. 2006;58(5):788-98.

17. Monteiro L. Valores de referência do RDW-CV e do RDW-SD e sua relação com o VCM entre os pacientes atendidos no ambulatório do Hospital Universitário Oswaldo Cruz-Recife, PE. Rev Bras Hematol Hemoter. 2010;32(1):34-9.

18. Farias MG, Dal Bó S. Importância clínica e laboratorial do volume plaquetário médio. J Bras Patol Med Lab. 2010;46(4):275-81.

\section{Correspondence:}

Iandara Schettert Silva

Avenida Senador Felinto Muller, s/n - Cidade Universitária

79080-190 Campo Grande - MS Brasil

ian.da.ra@hotmail.com

Received: Dec 12, 2013

Review: Feb 14, 2014

Accepted: March 18, 2014

Conflict of interest: none

Financial source: none

${ }^{1}$ Research performed at Experimental Laboratory, Animal Facility, Campo Grande-MS, Brazil. Part of Master degree thesis, Postgraduate Program in Health and Development, Federal University of Mato Grosso do Sul (UFMS). Tutor: Iandara Schettert Silva. 